\title{
Peat-fire-related Air Pollution in Central Kalimantan, Indonesia
}

Hiroshi Hayasaka ${ }^{a^{*}}$, Izumi Noguchi ${ }^{b}$, Eriant Indra Putra ${ }^{c}$, Nina Yulianti ${ }^{d}$, and Krishna Vadrevu ${ }^{e}$

a) Hokkaido University, Kita 13, Nishi 8, Kita-ku, Sapporo 060-8628, Hokkaido, Japan, Email:

hhaya@eng.hokudai.ac.jp

b) Inst. of Environ. Sci., Hokkaido Res. Org., Kita-19 Nishi-12, Kita-ku, Sapporo 060-0819 Japan, Email: izumi@hro.or.jp

\footnotetext{
${ }^{c)}$ Bogor Agricultural University, Bogor, Indonesia Email: eindraputra@yahoo.com

d) Palangkaraya University, Palangkaraya, Indonesia Email: nyu@gmail.com

e) University of Maryland, College Park, MD, USA Email: Krisvkp@umd.edu
}

\section{Abstract:}

The past decade marked record high air pollution episodes in Indonesia. In this study, we specifically focus on vegetation fires in Palangkaraya located near a Mega Rice Project area in Indonesia. We analyzed various gaseous air pollution data such as particulate matter (PM10), $\mathrm{SO}_{2}, \mathrm{CO}, \mathrm{O}_{3}$, and $\mathrm{NO}_{2}$ study region. We also conducted elemental analysis at two different sites. Results from 2001-2010 suggested the longest hazardous air pollution episode during 2002 lasting about 80 days from mid-August to late-October. Maximum peak concentrations of $\mathrm{PM} 10, \mathrm{SO}_{2}, \mathrm{CO}$, and $\mathrm{O}_{3}$ were also observed during 2002 and their values reached 1905, 85.8, 38.3, and $100310^{-6} \mathrm{gm}^{-3}$ respectively. Elemental analysis showed significant increase in concentrations during 2011 and 2010. Satellite retrieved fires and weather data could explain most of the temporal variations. Our results highlight peat fires as a major contributor of photochemical smog and air pollution in the region.

Key words: haze; peat fire; air pollutants; photochemical smog; PM10; MODIS.

\section{Capsule:}

Peat fires cause significant increase in gaseous pollutants and photochemical smog. 


\section{Introduction}

Biomass burning is a significant source of atmospheric greenhouse gas emissions and aerosols (Andreae and Merlet, 2001). In particular, tropical Asia is considered a major source of biomass burning (Streets et al., 2003; Vadrevu and Justice, 2011). In this region, several studies have reported significant biomass burning emissions from deforestation (Van Der Werf et al., 2008), slash and burn agriculture (Prasad et al., 2000; Varma, 2003; Langner et al., 2007), agricultural residue burning (Cheewaphongphan and Garivait, 2013; Badarinath et al., 2009; Vadrevu et al., 2011; 2012), management fires (Murdiyarso and Level, 2007), peatland burning (Siegert et al., 2001; Usup et al., 2004; Page et al., 2002; Heil et al., 2007), etc. Specific to peatlands, it is estimated that they account for 26-50 Gt of carbon in tropical Asia (Page et al., 2002) and thus a major source of carbon release during biomass burning.

Of the different countries in Asia, fires from peatlands and deforestation are most common in Indonesia (Usup et al., 2004). For example, fires in 1997-1998 in Indonesia consumed over 11 million ha of forest resulting in not only economic losses, but also threats to biodiversity, water supplies, and other ecosystem services (Siegert, 2001; Taylor, 2010; Hooijer et al., 2010). The resulting smoke plumes travelled long distances causing transboundary air pollution in the region (Heil and Goldammer, 2001). After the largest air pollution event that occurred in Indonesia in 1997, the governments of the ten Association of South East Asian Nations (ASEAN) member countries signed the ASEAN agreement on trans-boundary haze pollution on June 10, 2002 in Kuala Lumpur, Malaysia. The ASEAN Haze Agreement is the first regional arrangement in the world that binds a group of contiguous states to tackle trans-boundary haze pollution resulting from land and forest fires (Haze action on Line: http://haze.asean.org/).

In particular, haze in Indonesia results in serious environmental and health problems. For example, in 1994 and 1997 when extensive forest fires were reported in Indonesia, pronounced peaks of total and tropospheric ozone were observed at Watukosek, Indonesia (Fujiwara et al., 1999). The aerosols released by the 1997 fires resulted in severe air pollution in Southeast Asia. Daily mean PM levels reached $200010^{-6} \mathrm{~g} \mathrm{~m}^{-3}$ and higher in 
Indonesia during July through November, exceeding the ambient air quality standard by at least a factor of 7. Also downwind to the fires, Malaysia and Singapore experienced severe air pollution exceeding the typical air quality standards (Heil, 2007). The Indonesian fires in 1997 released pyrogenic aerosols of around $55 \times 10^{12} \mathrm{~g}$ PM10 into the atmosphere; the equivalent to around one-third of the global annual anthropogenic emissions of primary particles (Heil et al., 2005). Indonesia also formally admitted to releasing a very large amount of $\mathrm{CO}_{2}$ emissions from fires and deforestation (Nina, 2013).

In Indonesia, haze sources are mainly forest and peat fires associated with aggressive human activities with a very high deforestation rate of nearly $2 \% \mathrm{yr}^{-1}$ (ca.15, 000 $\left.\mathrm{km}^{2} \mathrm{yr}^{-1}\right)$. Vegetation fires in Indonesia could become very severe under severe El Niño and quasi-El Niño conditions, like in 1982-83, 1997-1998, 2002, 2004, 2006, and 2009. In particular, peat fires could become an even worse air pollution source due to its smoldering combustion and underground fires. For example, Indonesia has about $225,000 \mathrm{~km}^{2}$ of peatland ( $83 \%$ in Southeast Asia) of which, 57,600 and $30,100 \mathrm{~km}^{2}$ are in Kalimantan and Central Kalimantan respectively (GLC 2000). A large Mega Rice Project (MRP) was carried out near Palangkaraya, Central Kalimantan. The MRP area consists of 9,191 km² peat swamps. This kind of large-scale land development resulted in extensive deforestation (Main Synthesis report, 2008). The $4,000 \mathrm{~km}$ long irrigation system in the MRP is not functioning properly, and as a result, bare peatlands are highly vulnerable to fires during the dry season. MRP peat with roughly $4,500 \mathrm{~km}^{2}$ is more than $3 \mathrm{~m}$ deep and is the main source of fire-related air pollution.

In 2013, Singapore's worst air pollution event in the past 16 years occurred on June 19th, where the Pollutant Standards Index (PSI) reached 371 (International Business Times, Thursday, June 20, 2013, http://www.ibtimes.com/). Haze came from about $250 \mathrm{~km}$ away where vegetation fires occurred in the east of Dumai, Riau Province, Sumatra in Indonesia. To reduce trans-boundary haze pollution from vegetation fires, information on pollution sources and their impacts need a thorough investigation. For urban air pollution sources, there are several reports in Indonesia, but only a few for vegetation fires (Pradanil and Lestari, 2010). 
To assess the impact of peat fires on air pollution, we analyzed $\mathrm{PM} 10, \mathrm{SO}_{2}, \mathrm{CO}, \mathrm{O}_{3}$, and $\mathrm{NO}_{2}$ data obtained from the Air Pollution Center in Palangkaraya, in conjunction with MODIS satellite data fire hotspots and local weather data. In addition, we also carried out field surveys in severe peat fire areas to characterize the behavior of haze. Conditions and air pollution sources in 2002 and photochemical smog occurrence in Palangkaraya will be discussed based on field survey results.

\section{Data and Methodology}

\subsection{Hotspot (Fire) Data and Weather Data}

Daily MODIS hotspot data from 2002 to 2011 were extracted from the Fire Information for Resources Management System (https:v/earthdata.nasa.gov/data/nearreal-time-data/firms). Also, daily Advanced Very High Resolution Radiometer (AVHRR) hotspot data from 1997 to 2001 were obtained from JICA-SiPongi (http://www.indofire.org/). These data indicated the main air pollution sources of peatland burning in Palangkaraya.

Fig. 1 shows the location of Palangkaraya along with the distribution of MODIS hotspots. Palangkaraya is located in Central Kalimantan $\left(2.207^{\circ} \mathrm{S}, 113.917^{\circ} \mathrm{E}\right)$. The distance from the nearest coastline is about $100 \mathrm{~km}$ and the average altitude is only around $10 \mathrm{~m}$. The MRP was built in tropical swamp forest areas in the east and southern side of Palangkaraya. Before the disturbance, the tropical swamp forest could hold enough water to stay wet during the dry season. However, the newly constructed 4,000km-long MRP canal built for irrigation facilitated not only illegal logging, but also loss of water through drainage from most of the peatlands in the MRP area. This is one of the reasons for severe fire occurrence in the MRP area.

Circles in Fig. 1 show annual average fire occurrence in each 0.5 degree grid cell in Kalimantan. Analysis using MODIS hotspot data for recent years from 1997 to 2012 suggested the highest number of hotspots of 901 (hotspots $\mathrm{yr}^{-1}{ }^{-1}$ ) in a grid located in the south of Palangkaraya. Grids with the second and third highest number of hotspots of 666 and 632 were also found in the vicinity of Palangkaraya. The study area is shown in Fig.2. In total, 12 grid cells of 0.1 degrees ranging from 2.125 to 2.425 south latitude and from 113.8 
to 114.2 east longitude. The total number of hotspots during the fire season ( $D N=200 \sim 329$ or rate July to November) from 2002 to 2012 varied from 998 in 2002 to 0 in 2010. The number of hotspots in 2002, 2006, and 2009 were 998, 476, and 793 respectively, and the fires for these years exceeded the typical average of 278 fires. Thus, we denote the above years as fire years and the other years as non-fire years. This classification is closely related to El-Nino years and non-El-Nino years. This is simply because peat becomes flammable only under low moisture content or under sever drought conditions due to El-Nino events. Weather data measured at Palangkaraya Airport (Tjilik Riwut, $2.224^{\circ} \mathrm{S}, 113.946^{\circ} \mathrm{E}$ ) were obtained from Palangkaraya University and were used for the assessment of fire and haze conditions.

\subsection{Air Pollution Data}

The air pollution in Palangkaraya was monitored by the Air Quality Management System and regional Center, Palangkaraya city. The locations of the three measuring stations are Tjilik Riwut (P-1), Tilung (P-2) and Murjani (P-3), and they are shown in Fig. 2. Each station measured $\mathrm{PM} 10, \mathrm{SO}_{2}, \mathrm{CO}, \mathrm{O}_{3}$, and $\mathrm{NO}_{2}$, by using automated continuous analyzers. The Air Quality Center processes all air pollution data automatically every thirty minutes and displays their values along with the Air Pollution Standard Index (APS) every day (update time at 15:00) located in the $100 \mathrm{~m}$ rotary in Palangkaraya. Unfortunately, this system was broken in 2011 and data were unavailable. Accordingly, we restrict our analysis from 2001 till 2010.

\subsection{Pollutant Sampling for Chemical analysis}

An air pollution survey was conducted at an urban site in UNPAR (University of Palangkaraya), and at a rural site in Taruna, as shown in Fig. 2. The site in Taruna is located in the southeast of the UNPAR site with $20 \mathrm{~km}$ between each site. The two rivers of Kahayan and Sebangau run along both sides of Taruna and small farmland was found on both sides of the road. However, most of the land was abandoned farmland with severely burned forest and bush land.

The filter-pack method (FP) in Fig. 3 and the passive sampler method (PS) were used in this study (EANET, 2003; Noguchi et al., 2007). Both methods are already used by the 
international air pollution monitoring networks such as EANET (Acid Deposition Monitoring Network in East Asia).

Chemical analysis was conducted for FP and PS. FP collected elemental carbon (EC), organic carbon (OC), particle ion components $\left(\mathrm{SO}_{4}{ }^{2-}, \mathrm{NO}_{3}{ }^{-}, \mathrm{Cl}^{-}, \mathrm{F}^{-}, \mathrm{Na}^{+}, \mathrm{K}^{+}, \mathrm{Mg}^{2+}, \mathrm{Ca}^{2+}\right.$ and $\left.\mathrm{NH}_{4}{ }^{+}\right)$, sulfur dioxide $\left(\mathrm{SO}_{2}\right)$, nitric acid $\left(\mathrm{HNO}_{3}\right)$, nitrous acid (HONO), and ammonia $\left(\mathrm{NH}_{3}\right)$. Nitrogen dioxide $\left(\mathrm{NO}_{2}\right)$ was collected using PS.

\section{Results and Discussion}

\subsection{Analysis of Air Pollution Data in Palangkaraya}

3.1.1 $\mathrm{PM} 10, \mathrm{SO}_{2}, \mathrm{CO}, \mathrm{O}_{3}$, and $\mathrm{NO}_{2}$ in 2002

Very severe peat fires occurred near Palangkaraya in 2002, two years after the Air Quality Management System started to measure air pollutants. Daily measured values of $\mathrm{PM} 10, \mathrm{SO}_{2}, \mathrm{CO}, \mathrm{O}_{3}$, and $\mathrm{NO}_{2}$ during the fire season from August to November in 2002 were shown in Fig. 4. Most air pollutants except $\mathrm{NO}_{2}$ showed a similar trend. Maximum concentrations of PM10, $\mathrm{SO}_{2}, \mathrm{CO}$, and $\mathrm{O}_{3}$ were observed on October 14 in 2002 and their values were $1905,85.8,38.3$, and $100310^{-6} \mathrm{~g} \mathrm{~m}^{-3}$ respectively. API was also highest with 1805. These air pollutant peaks occurred just after the hotspot (fire) peak on October 12 in 2002.

$\mathrm{NO}_{2}$ showed slightly different emission trends as shown in Fig.4. Daily $\mathrm{NO}_{2}$ varied greatly from 7.3 to $67.410^{-6} \mathrm{~g} \mathrm{~m}^{-3}$ during the fire season. To compare the $\mathrm{NO}_{2}$ values both in fire and non-fire season, monthly averaged $\mathrm{NO}_{2}$ values were calculated. The average $\mathrm{NO}_{2}$ value during the fire season from August to October was $30.510^{-6} \mathrm{~g} \mathrm{~m}^{-3}$. In contrast, the average $\mathrm{NO}_{2}$ value during the non-fire season from January to June was $13.610^{-6} \mathrm{~g} \mathrm{~m}^{-3}$. This difference of $\mathrm{NO}_{2}$ between fire and non-fire season may suggest two major air pollution sources, namely one from vegetation fire and another from combustion in vehicle engines. In other words, $\mathrm{NO}_{2}$ showed relatively lower values during the non-fire season simply because the primary emission source is engines. During the fire season, peat fires will mainly emit $\mathrm{NO}_{2}$, and thus the data showed relatively higher values. Under high $\mathrm{NO}_{2}$ conditions, the $\mathrm{O}_{3}$ peak occurred on October 14. This may suggest serious formation of photochemical smog. 
Large differences found in $\mathrm{PM} 10, \mathrm{SO}_{2}$, and $\mathrm{CO}$ during the fire season in Fig.4 also suggest a large contribution from peat fires. Especially, increased $\mathrm{SO}_{2}$ from around $510^{-6} \mathrm{~g}$ $\mathrm{m}^{-3}$ in early-August to $85.810^{-6} \mathrm{~g} \mathrm{~m}^{-3}$ in mid-October (see Fig.4) was mostly from peat fires, as there is no other major source of $\mathrm{SO}_{2}$ (such as industries) in the vicinity.

As most API were derived from PM10 in 2002, a horizontal line was drawn at PM10= $42010^{-6} \mathrm{~g} \mathrm{~m}^{-3}$ to show the hazardous Level of API (>300). Thus from Fig.4, we infer that the hazardous condition lasted about 80 days from mid-August to late-October in 2002.

\subsubsection{PM10 in Fire and Non-Fire Years}

Severe fires occurred in 1997, 2002, 2006, and 2009 in Kalimantan (fire years). PM10 trends for fire years were shown in Fig.5. 2002 showed the highest peak of PM10 and 2006 and 2009 followed the trend. Number of days of hazardous level of API>300 were about 80 days in 2002 and 60 and 30 days respectively during 2006 and 2009.

PM10 levels in non-fire years, 2003, 2005, and 2010 were shown in Fig.6. Their number of hotspots and standard deviation factors were 124,55 , and 0 , and $-0.45,-0.65$ and -0.82 , respectively. From Fig.6, PM10 in most years except 2010, the wettest year, exceeded moderate levels in August and September. It is evident from Figs. 5 \& 6 that PM10 levels in Palangkaraya were very high and posed severe pollution problems in the region.

\subsubsection{Chemical Analysis Results}

Chemical analysis was carried out in the non-fire years of 2010, 2011, and 2012 for pollutant levels. Each year, two pollutant samples were collected at two sites in urban (UNPAR) and rural (Taruna) areas and analyzed using the filter-pack method (FP) method (Fig. 3). Peat fires were not observed in 2010 due to frequent precipitation during the dry season, but in 2011, fires were observed often in both sites. In 2012, fires occurred in the south of Taruna. The observed air pollutant concentrations are shown in Table 1, with site information in Table 2. During 2011, concentrations of $\mathrm{SO}_{2}$ and $\mathrm{SO}_{4}{ }^{2-}$ (indicators of peat fire), $\mathrm{NO}_{3}{ }^{-}, \mathrm{EC}, \mathrm{OC}, \mathrm{K}^{+}$, and $\mathrm{HNO}_{3}$ (indicator of vegetation fires or fuel $\mathrm{N}$ ) were higher than during 2010 and 2012 at Taruna. It is inferred that these air pollutant concentrations were due to an increase in peat fires. In addition, particulate matter concentrations were also higher than that of gas components, where concentrations of $\mathrm{SO}_{4}{ }^{2-}$ were larger than $\mathrm{SO}_{2}$ 
concentrations. Furthermore, the concentrations of $\mathrm{SO}_{4}{ }^{2-}, \mathrm{K}^{+}$, and $\mathrm{NH}_{4}{ }^{+}$were also relatively high in East Asian records (EANET, 2013; JELA, 2013) as shown in Table 3, except for the 2010 Taruna record, when no fires were present.

The concentrations of $\mathrm{HONO}, \mathrm{NO}_{2}$, and $\mathrm{NH}_{3}$ in 2011 are higher than those recorded in 2010. The concentrations reported in 2012 are of the same magnitude as 2010 . These results indicate that peat fires were the prominent contributor to air pollution in Taruna during 2011. The effects of peat fires in 2012 seemed to be negligible for $\mathrm{HONO}, \mathrm{NO}_{2}$, and $\mathrm{NH}_{3}$ because the fires were located far from Taruna. Moreover, it should be noted that the $\mathrm{NH}_{3}$ concentrations were higher than other gases and particulate components. Those concentrations were relatively high in East Asian records (EANET-2013, JELA-2013) despite a lack of fire in 2010.

Relating to the survey results obtained at the city site (UNPAR), the concentrations of many components are higher than those observed at Taruna. This is mainly attributed to the emissions from not a few garbage incineration places in the open space of the city. However, particle components such as $\left(\mathrm{NH}_{4}\right)_{2} \mathrm{SO}_{4}{ }^{2-} / \mathrm{NH}_{4} \mathrm{HSO}_{4}$ seemed to be of the same magnitude, or exhibited only minor differences between both sites. The concentrations of $\mathrm{SO}_{4}{ }^{2-}$ and $\mathrm{NH}_{4}{ }^{+}$ are similar between 2011 hot spot areas, but in 2012 were much different between hot spot areas. It is recognized that those fine particulates are easily transported across a wide area. In addition, fine particulate such as $\mathrm{PM}_{2.5}$ is also easily absorbed into the lungs and has a high risk to human health (Harrison and Yin, 2000). Thus, the human health risk is equally high both inside and outside fire affected areas.

\subsection{Haze and Air Pollution Sources (Peat Fire areas) in Palangkaraya}

\subsubsection{Observation of Haze}

MODIS satellite images for fire years of 2002, 2004, and 2006 were shown in Fig.7. These images suggest that haze is transported from southeast to northwest, which is the prevailing wind direction during the dry (fire) season in Kalimantan. Hotspots are not always found near thick haze, and vice-versa. Ground observations were carried out near Taruna during the most severe fire occurrence period in 2009 and the haze conditions are shown in Fig.8. This picture was taken at noontime, however, very low visibility due to haze can be noted (Fig.8). Under this dense haze condition, sunlight could not reach the ground easily 
suggesting that daytime convection flow by the sunlight barely occurred on these days and the haze was confined to the surface. Thus, haze just moved horizontally with the prevailing wind. This phenomenon is one of the reasons for the highest API value (1805) during August, 2002.

In Fig.9, visibility observed at Palangkaraya Airport was shown along with mean and gust wind speed. The lowest visibility of almost zero was observed on October 2 (Fig.9). Low visibility conditions less than $1 \mathrm{~km}$ lasted about 70 days from late-August to late-October. About 16 days from $\mathrm{DN}=260$ in late September, visibility was less than $0.5 \mathrm{~km}$ and wind speed was also very slow (mean wind speed less than $2 \mathrm{~m} \mathrm{~s}^{-1}$ ) (Fig.9).

\subsubsection{Air Pollution Sources (Peat Fire Areas)}

The distribution of hotspots near Palangkaraya during the fire season in 2002 were visualized on a Google map in Fig.10. Distance and direction from the city center were shown by circles and straight lines. Locations of each hotspot (fire) were plotted by yellow, cyan, and red solid squares at each coordinate. Different colors were used to show the hotspot detection period. Yellow squares showed hotspots detected during the active fire season from August to October ( $\mathrm{DN}=210-310)$. Two other colors of cyan and red were used to show different periods of $\mathrm{DN}=260-269$ and $\mathrm{DN}=280-289$ respectively. These two periods were specially selected because they were the worst air pollution periods in 2002 (see Fig.6).

From Fig.10, we could identify several concentrated hotspot areas surrounding Palangkaraya. In 2002, the densest hotspot area was identified near "Taruna" located about $15-20 \mathrm{~km}$ from Palangkaraya with the prevailing wind direction being southerly. Other dense hotspot clusters were found in the "MRP Block E-West" area about 10-15km northeast, "Main Channel" area about 15-25km northeast, "North of Sebangau NP" area about 10$15 \mathrm{~km}$ southwest, and "West of Palangkaraya" area about $10-15 \mathrm{~km}$ west. All of these locations are candidates for air pollution sources for Palangkaraya. In addition to these, several scattered fire clusters were located near Palangkaraya center. They could also be a source of dense haze due to the short distance from the city center.

To understand the air pollution impacts due to peat fire in Palangkaraya in 2002, daily fire hotspots were plotted for the fire season along with PM10 (Fig. 11). PM10 
increased from around $5010^{-6} \mathrm{~g} \mathrm{~m}^{-3}$ in early-August to a maximum value of $190510^{-6} \mathrm{~g} \mathrm{~m}^{-3}$ in mid-October. On the contrary, the number of hotspots showed a zigzag pattern from midAugust to late-September. These different trends of PM10 and hotspots are due to the unique nature of peat fires near Palangkaraya and MODIS fire detection abilities. Similar to vegetation fires, peat fire needs an ignition source. However, once a peat fire starts, it expands gradually due to relative slow smoldering combustion and underground peat fire will not extinguish until the start of the rainy season (Fig.11). A peat fire expansion is originally very slow but could make a vegetation fire active depending on condition of ground fuels. This is one of reasons for the zigzag pattern of hotspots (Fig.11) detected by MODIS. Another reason is due to dense haze (low visibility in Fig. 9) from peat fires.

In contrast, the increasing trend of PM10 in Fig.11 implies increased air pollutant sources due to the increased number of vegetation fires and steady peat fire expansion. We note the change of PM10 trend from early-October (day number around 270) (Fig. 11) and this decreasing trend of PM10 is due to seasonal change from dry to wet season. Northerly winds started and brought rains (Fig.11), however, under this seasonal change in weather, the hotspot peak still occurred on October 12 in 2002 and two days later PM10 and $\mathrm{O}_{3}$ had their peaks (see Fig.5). Serious formation of photochemical smog may occur under clearer sky conditions or with sufficient sunlight made by a northerly wind and rainfall $(4.4 \mathrm{~mm}$ on October 5, see Fig.11). After this event, peat fires were naturally and gradually extinguished in mid-November due to heavy rainfall of about $58 \mathrm{~mm}$ on October 14 .

Fig. 12 identifies air pollution sources (peat fire areas) for Palangkaraya in 2002. The daily number of hotspots in three candidate locations for air pollution sources were "Taruna", "MRP Block E-West", and "West of Palangkaraya" plotted in Fig. 12 along with daily mean wind direction.

First, we noticed the seasonal wind direction change from dry (fire) to wet season occurred around late-September from a wind direction curve in Fig. 12. A fitting curve with a dotted line in Fig. 12 clearly shows a change from southeasterly to southwesterly wind. In addition, we should note the increase of northerly and westerly wind days.

We hypothesize that hotspots (fires) in "Taruna" are a constant source of haze throughout the fire season, as it was the densest hotspot area (see Fig.10) and fires started from late-July and lasted throughout the fire season (Fig.12). A southeasterly wind during 
the fire season could result in haze events in Palangkaraya area. Fires which occurred in "West of Palangkaraya" area during DN=260-270 were shown with blue rectangles in Fig.12. They may contribute to the high PM10 period before the end of the dry season (see Fig11), as "West of Palangkaraya" is located near the city center (see cyan squares in Fig.10).

The highest number of hotspots in "Taruna" and "MRP Block E-West" occurred on the same day of $\mathrm{DN}=285$ (see Fig12). These fires may be the main source for the highest PM10 peak in Fig. 10 on DN=287 (see Fig11). Firstly, "Taruna" was the main contributor under southerly wind conditions. Secondly, "MRP Block E-West" could be the main air pollution source when wind direction changed from southerly to northerly from around $\mathrm{DN}=287$ (see Fig12).

\section{Conclusions}

Results clearly suggest intense peat fires during 2002. In addition, we noted important pollution characteristics before the formation of photochemical smog. First, dense haze (PM10 exceeded more than $100010^{-6} \mathrm{~g} \mathrm{~m}^{-3}-\mathrm{DN}=262 \sim 270$ ) from fires in "West of Palangkaraya" resulted in very low visibility conditions. Second, weak wind conditions (less than $1 \mathrm{~m} \mathrm{~s}^{-1}$; day numbers=262 till 276) occurred under dense haze. Third, fire activities in "West of Palangkaraya" became weakened under low wind speed conditions and PM10 decreased from around 1000 to $50010^{-6} \mathrm{~g} \mathrm{~m}^{-3}$ (day numbers=271 till $273 \& 278$ till 280). Fourth, the situation gradually subsided with the help of recovering daytime convection and relatively strong southerly winds. On day number 285 , the largest number of hotspots (fires) near Palangkaraya area in 2002 occurred mainly in "MRP Block E-West" and "Taruna" (on day number 285). Finally, serious formation of photochemical smog $\left(\mathrm{O}_{3}\right.$ peak $=100010^{-6} \mathrm{~g} \mathrm{~m}^{-3}$ on day 287) occurred just after the fire peak under relatively strong sunshine conditions assisted by northerly winds (day number 287). From these results and discussions, we recommend strong conservation measures of peatlands in and around Palangkaraya. In particular, we suggest limiting the construction of irrigation canals which contribute to further development and subsequent drying of the land. Alternatives to fires should be explored as new means of land use/land management practices in Indonesia.

\section{Acknowledgement}


This research was partially supported by the JST-JICA Science and Technology Research Partnership for Sustainable Development (SATREPS) project on "Wild Fire and Carbon Management in Peat-Forest in Indonesia". For section 3.2, we would like to thank Dr. Sadamu Yamagata of the Hokkaido University for his support. The work of section 3.2 was also supported by a Grant-in-Aid for Scientific Research (24510023).

\section{References}

Andreae, M. O., \& Merlet, P., 2001. Emission of trace gases and aerosols from biomass burning. Global biogeochemical cycles. 15(4), 955-966.

Badarinath, K. V. S., Kharol, S. K., Sharma, A. R., \& Krishna Prasad, V., 2009. Analysis of aerosol and carbon monoxide characteristics over Arabian Sea during crop residue burning period in the Indo- Gangetic Plains using multi-satellite remote sensing datasets. Journal of Atmospheric and Solar-Terrestrial Physics, 71(12), 1267-1276.

Cheewaphongphan, P., \& Garivait, S., 2013. Bottom up approach to estimate air pollution of rice residue open burning in Thailand. Asia-Pacific Journal of Atmospheric Sciences, 49(2), 139149.

Country Synthesis Report on Urban Air Quality Management, Indonesia, 2006, C 2006 Asian Development Bank and the Clean Air Initiative for Asian Cities (CAI-Asia) Center, Discussion Draft, 25.

EANET (Acid Deposition Monitoring Network in East Asia), 2003. Technical Document for Filter Pack Method in East Asia. http://www.eanet.asia/product/index.html (last access 31/10/2013).

EANET (Acid Deposition Monitoring Network in East Asia), 2012. Data Report on the Acid Deposition in the East Asian Region 2010. http://www.eanet.asia/product/index.html (last access 31/10/2013).

Fujiwara, M., Kita, Kawakami, K.S., Ogawa T., Komala, N., Saraspriya, S., Suripto. A., 1999. Tropospheric ozone enhancements during the Indonesian forest fire events in 1994 and in 1997 as revealed by ground-based observations, GEOPHYSICAL RESEARCH LETTERS, 26$16,2417-2420$. 
Harrison, R. M., Yin, J., 2000. Particulate matter in the atmosphere: which particle properties are important for its effects on health? Science of the Total Environment, 249(1), 85-101.

Heil, A., 2007. Indonesian peat and vegetation fire emissions: Emissions, Air Quality, and Human Health, PhD Thesis, International Max Planck Research School.

Heil, A., \& Goldammer, J., 2001. Smoke-haze pollution: A review of the 1997 episode in Southeast Asia. Regional Environmental Change, 2(1), 24-37.

Heil, A. , Langmann, B., Aldrian, E., 2006.Indonesian Forest and Peat Fires, Mitig Adapt Strat Glob Change, DOI 10.1007/s11027-006-9045-6.

Heil, A., Langmann, B., \& Aldrian, E., 2007. Indonesian peat and vegetation fire emissions: Study on factors influencing large-scale smoke haze pollution using a regional atmospheric chemistry model. Mitigation and adaptation strategies for global change, 12(1), 113-133.

Hooijer, A., Page, S., Canadell, J. G., Silvius, M., Kwadijk, J., Wösten, H., \& Jauhiainen, J., 2010. Current and future $\mathrm{CO}_{2}$ emissions from drained peatlands in Southeast Asia. Biogeosciences, 7(5), 1505-1514.

IARC Scientific Publication No. 161, "Air Pollution and Cancer", Editors: Kurt Straif, Aaron Cohen, and Jonathan Samet, elSBN 978-92-832-2161-6, ISSN 0300-5085 (http://www.iarc.fr/en/publications/books/sp161/index.php)

JELA (Acid Deposition Monitoring Network in Japan Environmental Laboratories Association), 2013, Acid Deposition Survey in Japan, Phase (2011). Journal of Environmental Laboratories Association.38, 84-126 (in Japanese).

Langner, A., Miettinen, J., \& Siegert, F., 2007. Land cover change 2002-2005 in Borneo and the role of fire derived from MODIS imagery. Global Change Biology, 13(11), 2329-2340.

Main Synthesis report, 2008. Master Plan for the Rehabilitation and Revitalisation of the Ex-Mega Rice Project Area in Central Kalimantan. A Joint Initiative of the Governments of Indonesia and the Netherlands. file://localhost/(http/::www.geog.le.ac.uk:carbopeat:media:pdf: pub_technical_review\%25 201-science.pdf).

Murdiyarso, D., Lebel, L., 2007. Local to global perspectives on forest and land fires in Southeast Asia. Mitigation and Adaptation Strategies for Global Change, 12(1), 3-11. 
Nina, Y., 2013. PhD Thesis, Graduate School of Engineering, Hokkaido University, The Influence of Precipitation Patterns on Recent Peatland Fires in Indonesia.

Noguchi, I., Otsuka, H., Akiyama, M., Sakai, S., Kato, T., 2007. Measuring Concentrations of Nitrous Acid Gas by the Filter- Pack Sampling Method. Journal of Japan Society for Atmos. Environ., 42, 162-174 (in Japanese).

Page, S. E., Siegert, F., Rieley, J. O., Boehm, H. D. V., Jaya, A., \& Limin, S., 2002. The amount of carbon released from peat and forest fires in Indonesia during 1997. Nature, 420 (6911), 6165.

Pradani1, M., Lestari, P., 2010. CORRELATION BETWEEN HOTSPOTS AND AMBIENT AIR QUALITY AS IMPACT OF FOREST FIRE. AP4. (http://www.ftsl.itb.ac.id/kk/air_waste/wpcontent/uploads/2010/11/ PE-AP4-MAHARANI-PRADANI-15305022.pdf).

Prasad, K.V., K Gupta, P., Sharma, C., Sarkar, A. K., Kant, Y., Badarinath, K. V. S., \& Mitra, A. P., 2000. $\mathrm{NO}_{x}$ emissions from biomass burning of shifting cultivation areas from tropical deciduous forests of India- estimates from ground-based measurements. Atmospheric Environment, 34(20), 3271-3280.

Usup, A., Hashimoto, Y., Takahashi, H., Hayasaka. H, 2004, Combustion and Thermal Characteristics of Peat Fire in Tropical Peatland in Central Kalimantan, Indonesia, TROPICS, 14-1, 1-19.

Vadrevu, K. P., Ellicott, E., Badarinath, K. V. S., \& Vermote, E. (2011). MODIS derived fire characteristics and aerosol optical depth variations during the agricultural residue burning season, north India. Environmental Pollution, 159(6), 1560-1569.

Vadrevu, K. P., Ellicott, E., Giglio, L., Badarinath, K. V. S., Vermote, E., Justice, C., \& Lau, W. K. (2012). Vegetation fires in the himalayan region-Aerosol load, black carbon emissions and smoke plume heights. Atmospheric Environment, 47, 241-251.

Vadrevu, K. P., \& Justice, C. O. (2011). Vegetation Fires in the Asian Region: Satellite Observational Needs and Priorities. Global Environmental Research, 15(1), 65-76.

Van der Werf, G. R., Dempewolf, J., Trigg, S. N., Randerson, J. T., Kasibhatla, P. S., Giglio, L., DeFries, R. S., 2008. Climate regulation of fire emissions and deforestation in equatorial Asia. Proceedings of the National Academy of Sciences, 105(51), 20350-20355. 
Wetlands International, 2006., PEAT-CO2, Assessment of CO2 emissions from drained peatlands in SE Asia. Report R\&D projects Q3943 / Q3684 / Q4142. 


\section{List of Figs and Tables}

Fig. 1 Location of Palangkaraya in Kalimantan and Fire (Hotspot) Distribution by $0.5^{\circ}$ Grids

Fig. 2 Map of Study Area (Three Stations and Two Sampling Sites in Palangkaraya and Taruna)

Fig. 3 Filter-pack method (EANET, 2003; Noguchi et al., 2007)

Fig. $4 \mathrm{PM} 10, \mathrm{SO}_{2}, \mathrm{CO}, \mathrm{O}_{3}$, and $\mathrm{NO}_{2}$ in 2002

Fig. 5 PM10 Trends in Fire Years, 2002, 2006, and 2009

Fig. 6 PM10 Trends in Non-Fire Years, 2001, 2003, 2005, and 2010

Fig. 7 Haze in Kalimantan observed in 2002, 2004, and 2006

Fig. 8 Very Low Visibility Due to Haze from Peat Fires Near Taruna (2009. 9.21)

Fig. 9 Visibility and, Mean and Gust Wind Speed in 2002

Fig. 10 Hotspot (Fire) Distribution near Palangkaraya in 2002

Fig. 11 PM10 and Precipitation, and Hotspot near Palangkaraya in 2002

Fig. 12 Hotspots in Three Areas and Wind Direction

Table 1 Air Pollutant Concentrations

Table 2 Air Pollutant Concentration Ratios

Table 3 Air pollutant concentrations at reference sites in East Asia 


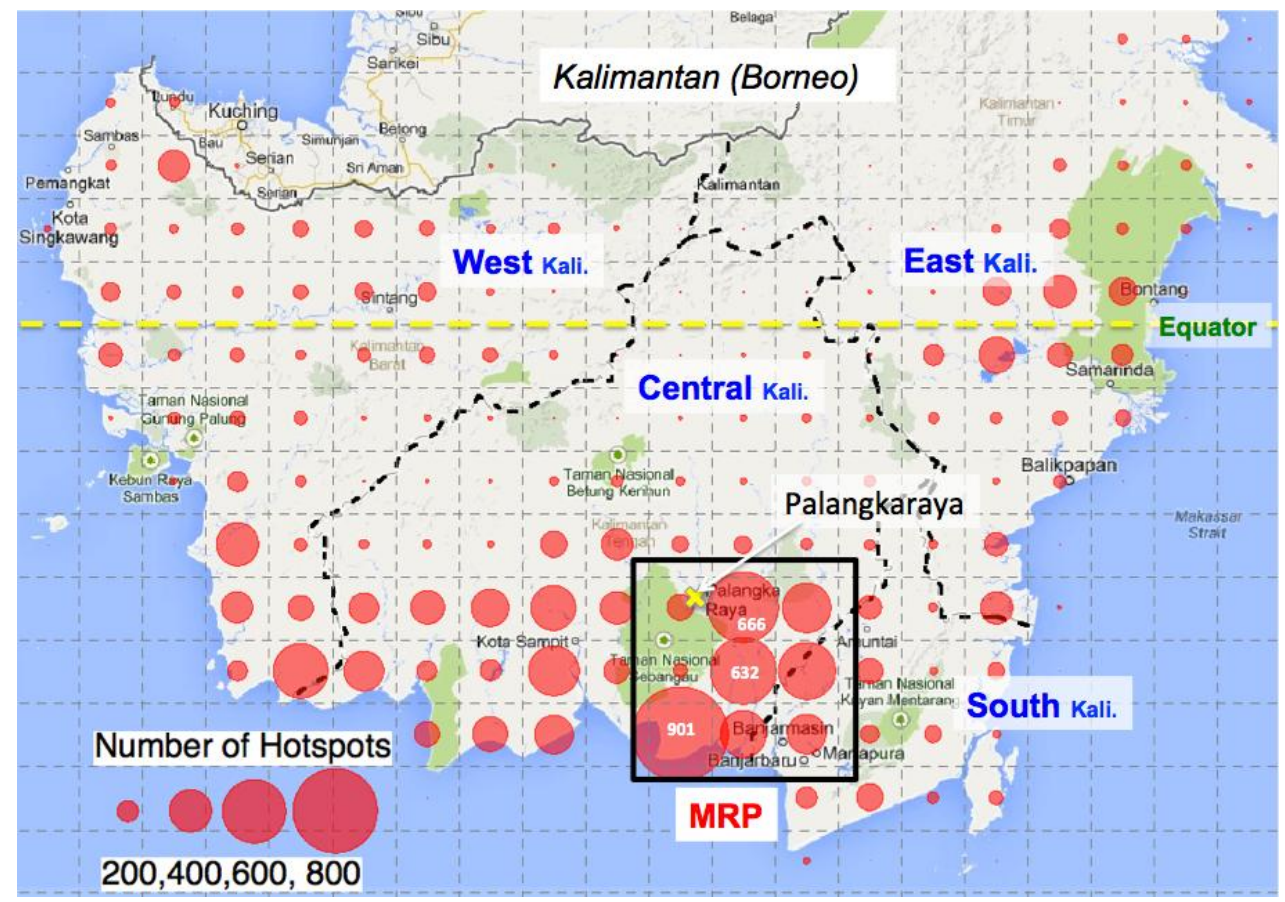

Fig. 1 Location of Palangkaraya in Kalimantan and Fire (Hotspots) Distribution by $0.5^{\circ}$ Grids

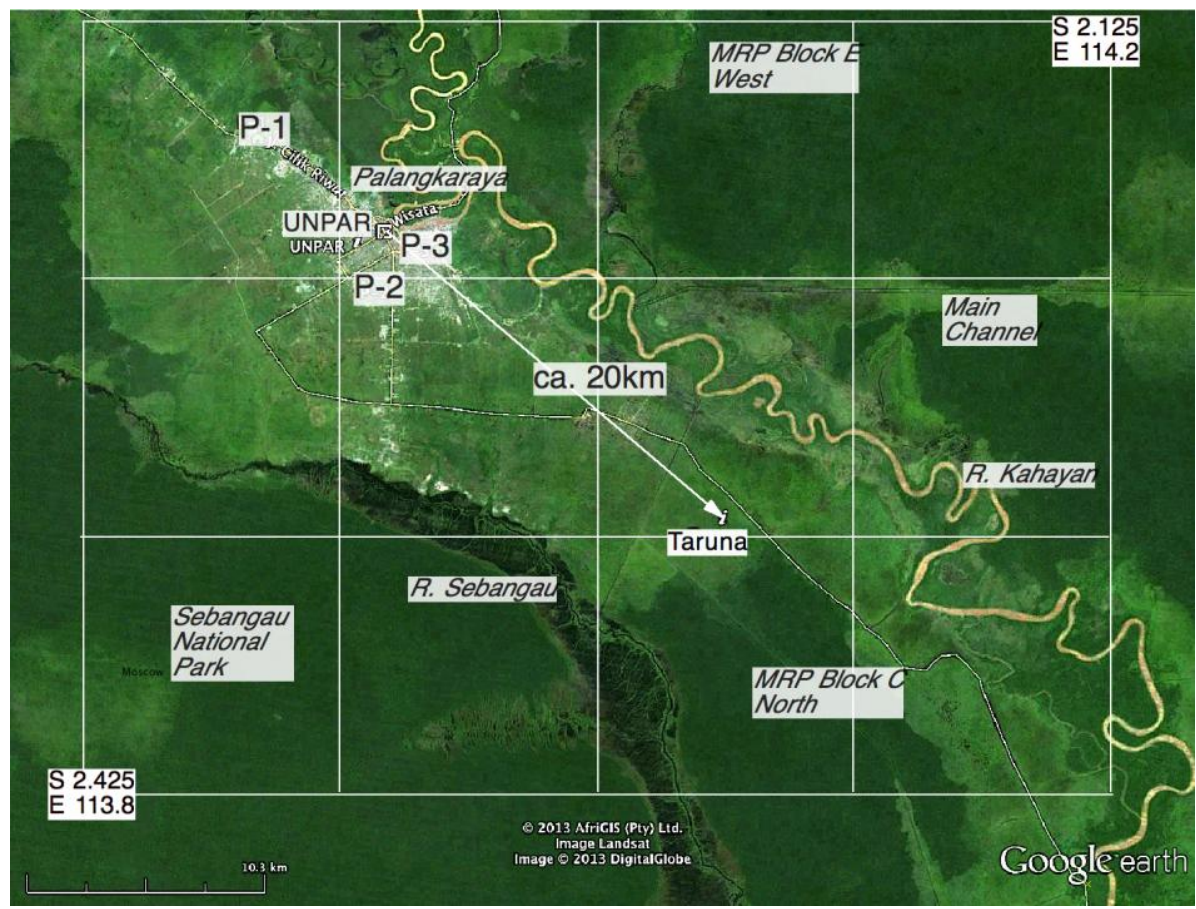

Fig. 2 Study Area (3 stations and 2 sampling sites in Palangkaraya and Taruna) 


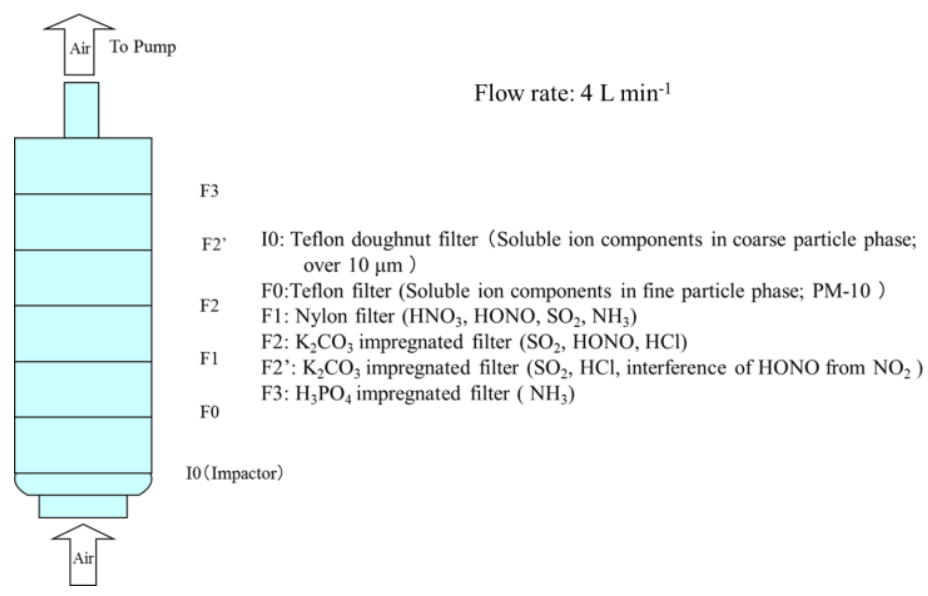

Fig.3 Filter-pack method (EANET, 2003; Noguchi et al., 2007)

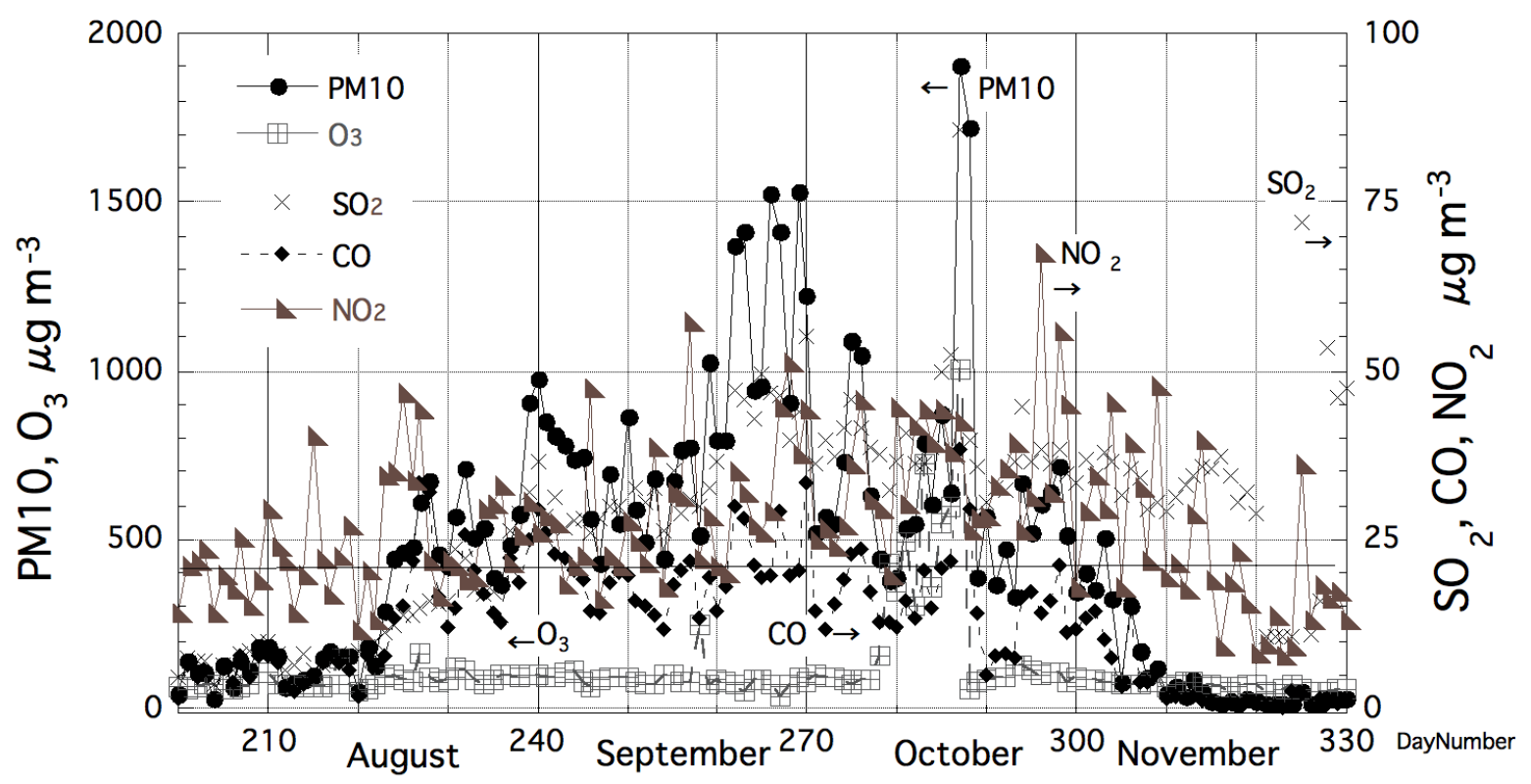

Fig. $4 \mathrm{PM} 10, \mathrm{SO}_{2}, \mathrm{CO}, \mathrm{O}_{3}$, and $\mathrm{NO}_{2}$ in 2002 


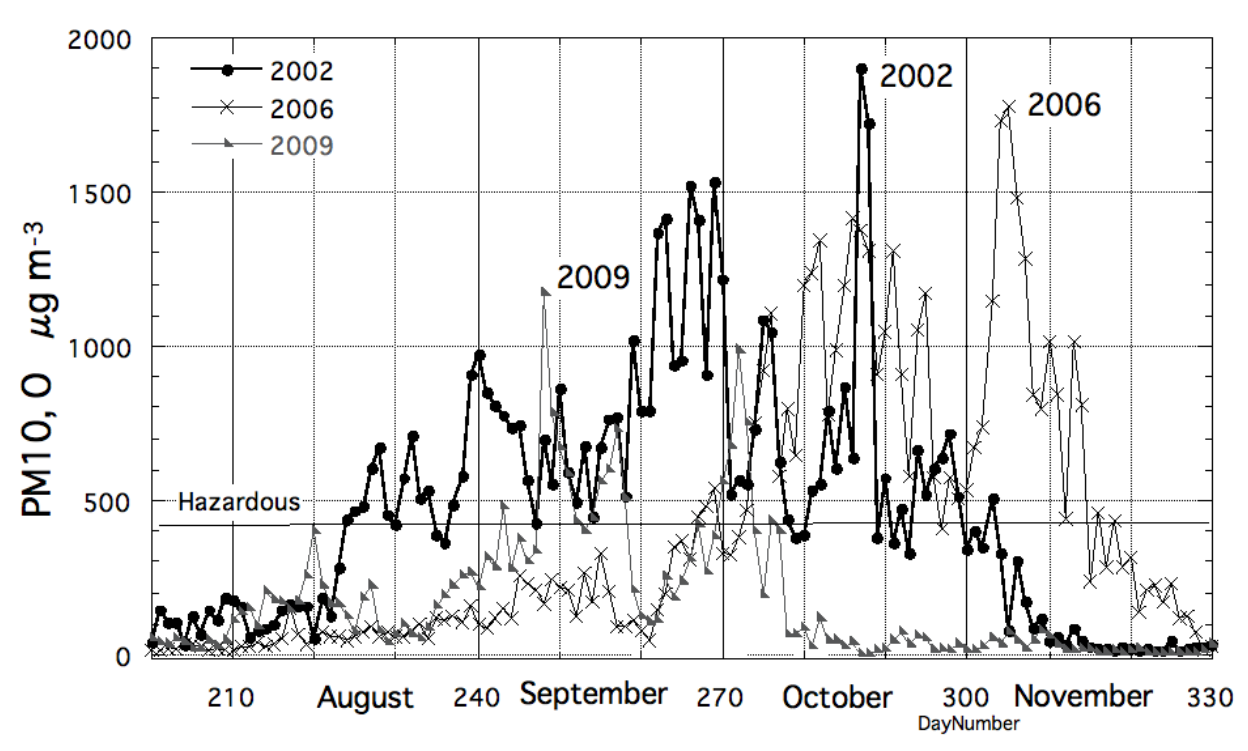

Fig. 5 PM10 trends during fire years $(2002,2006$, and 2009)

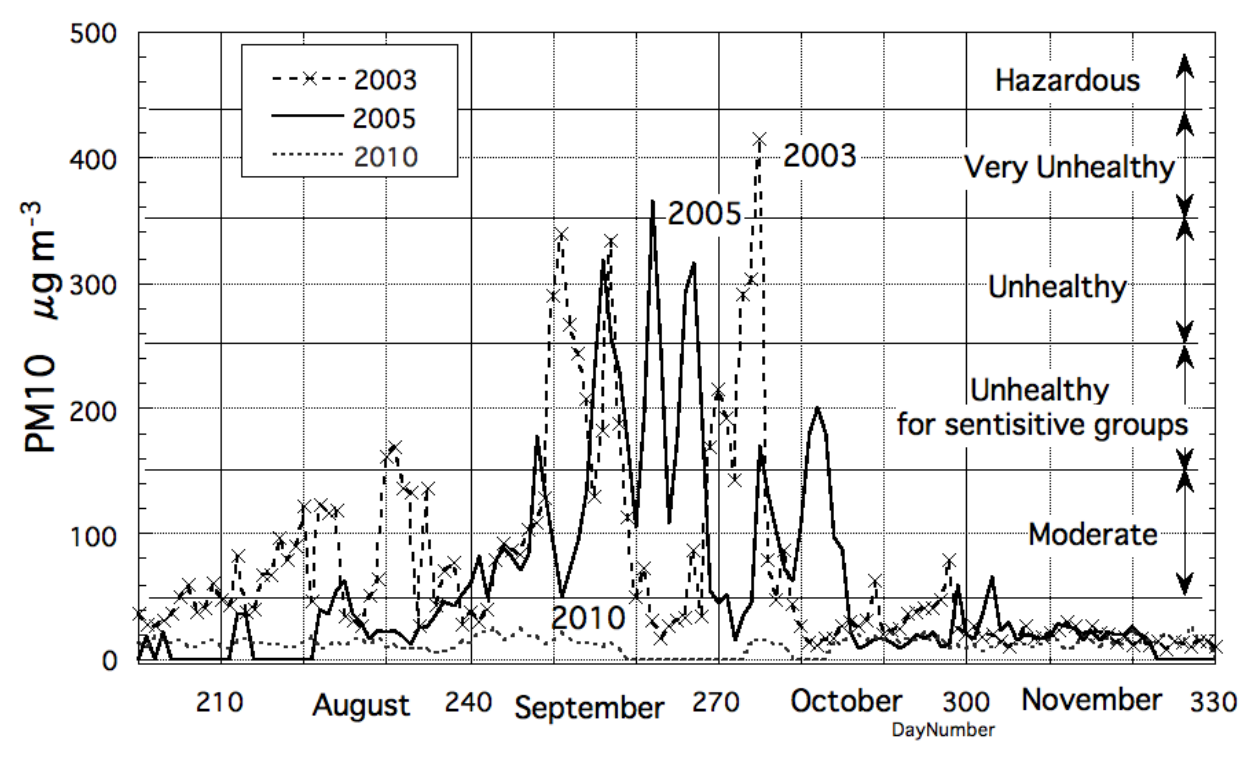

Fig. 6 PM10 Trends during non-fire years (2001, 2003, 2005, and 2010) 


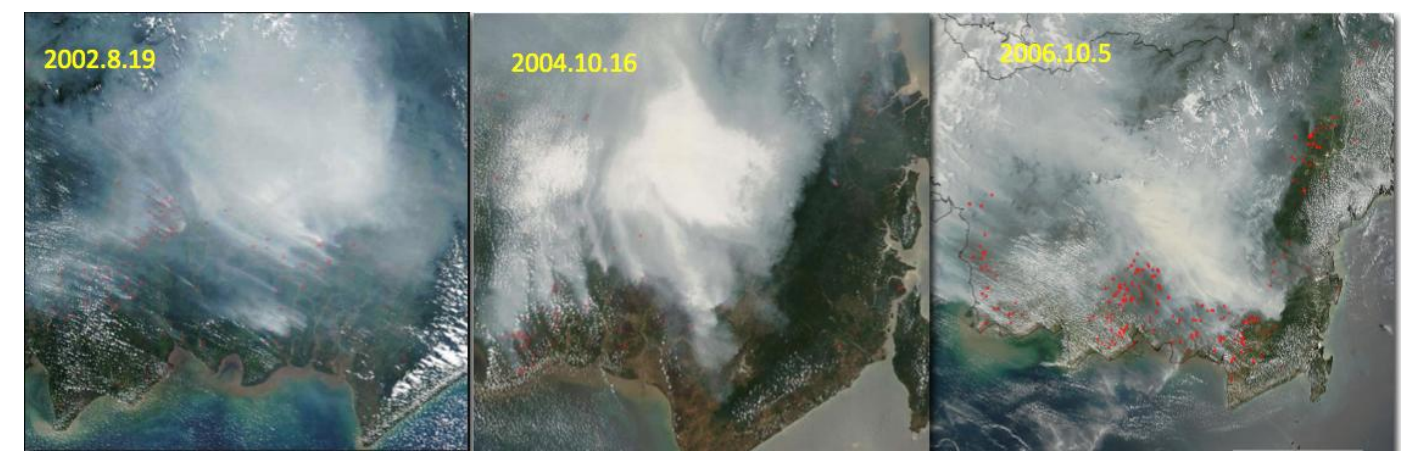

Fig. 7 Haze in Kalimantan observed during 2002, 2004, and 2006

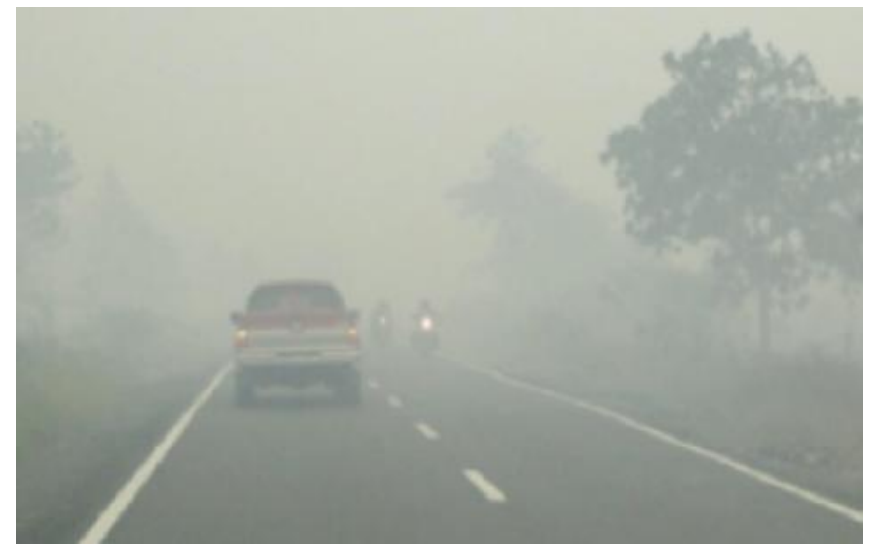

Fig. 8 Very Low visibility due to haze from Peat fires near Taruna (2009. 9.21)

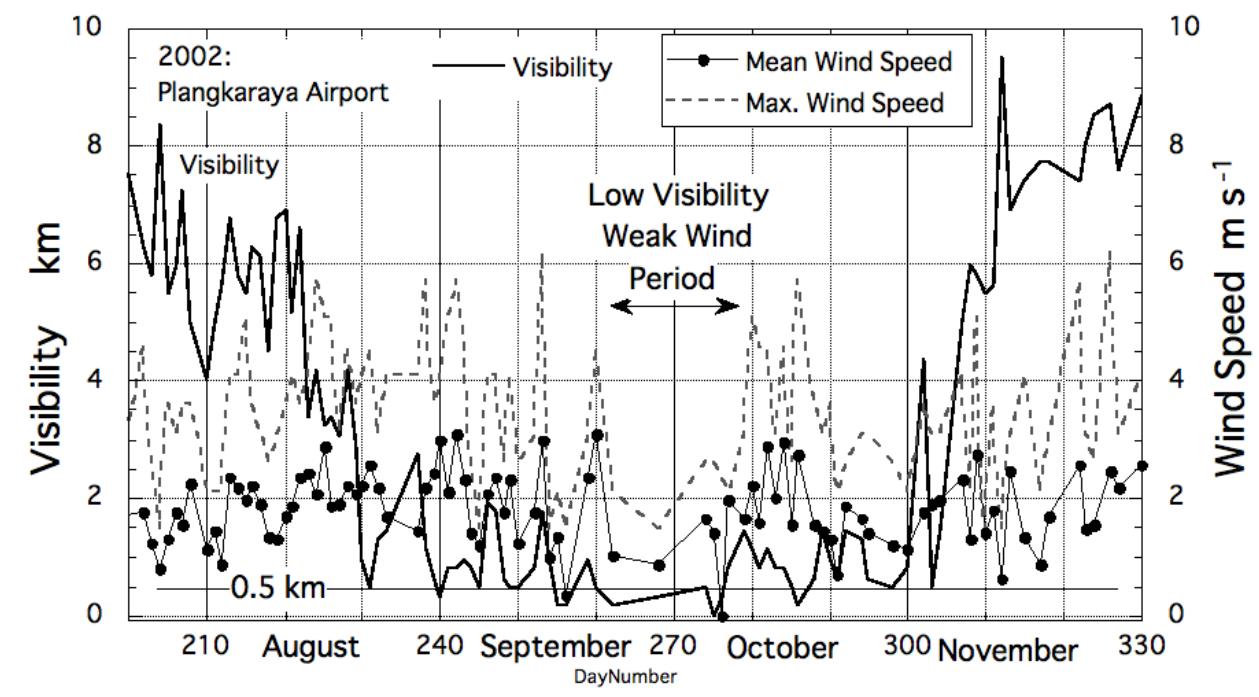

Fig. 9 Visibility and, mean and gust wind speed during 2002 


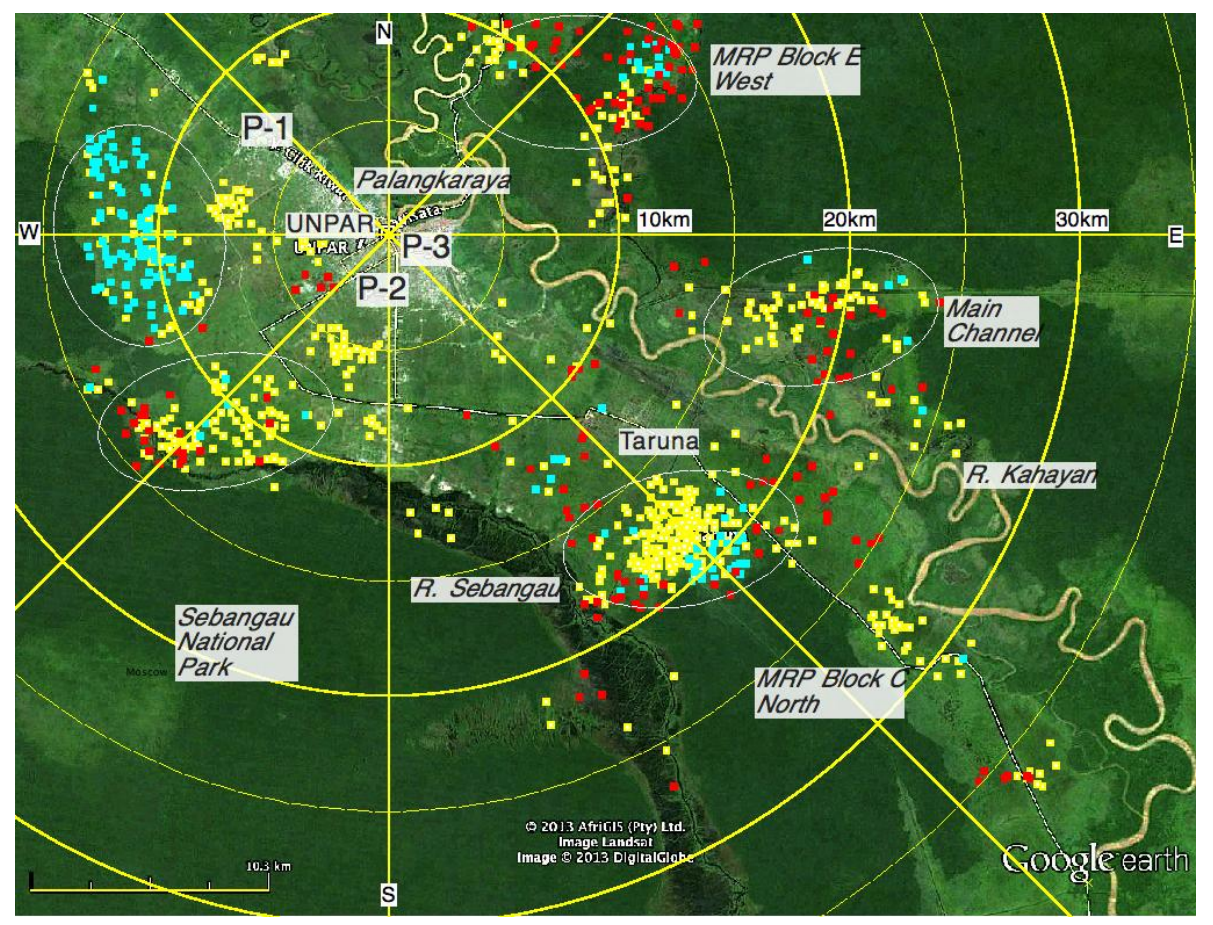

Fig. 10 Hotspot (fire) distribution near Palangkaraya during 2002

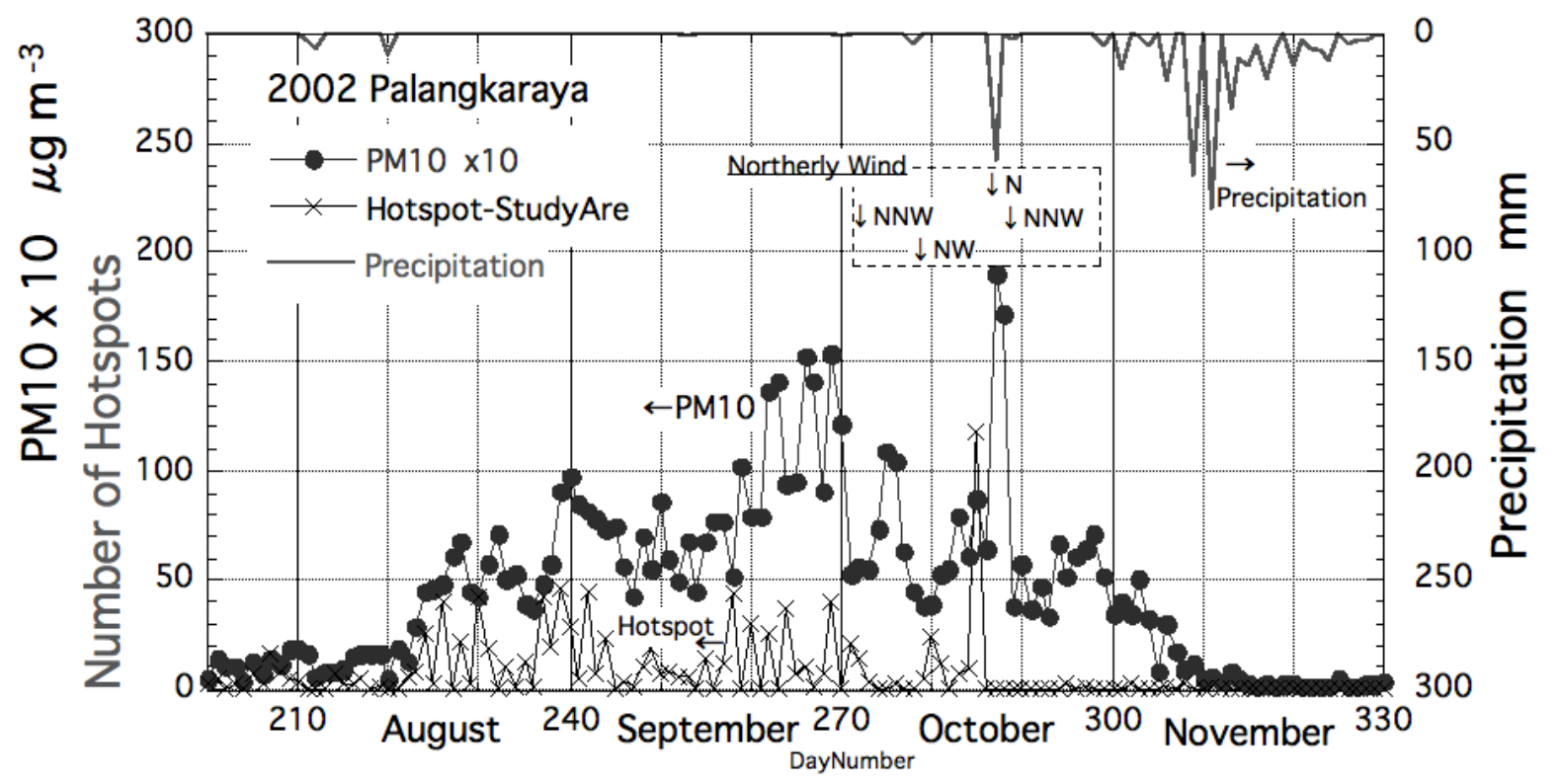

Fig. 11 PM10, precipitation and hotspot (fires) near Palangkaraya during2002 


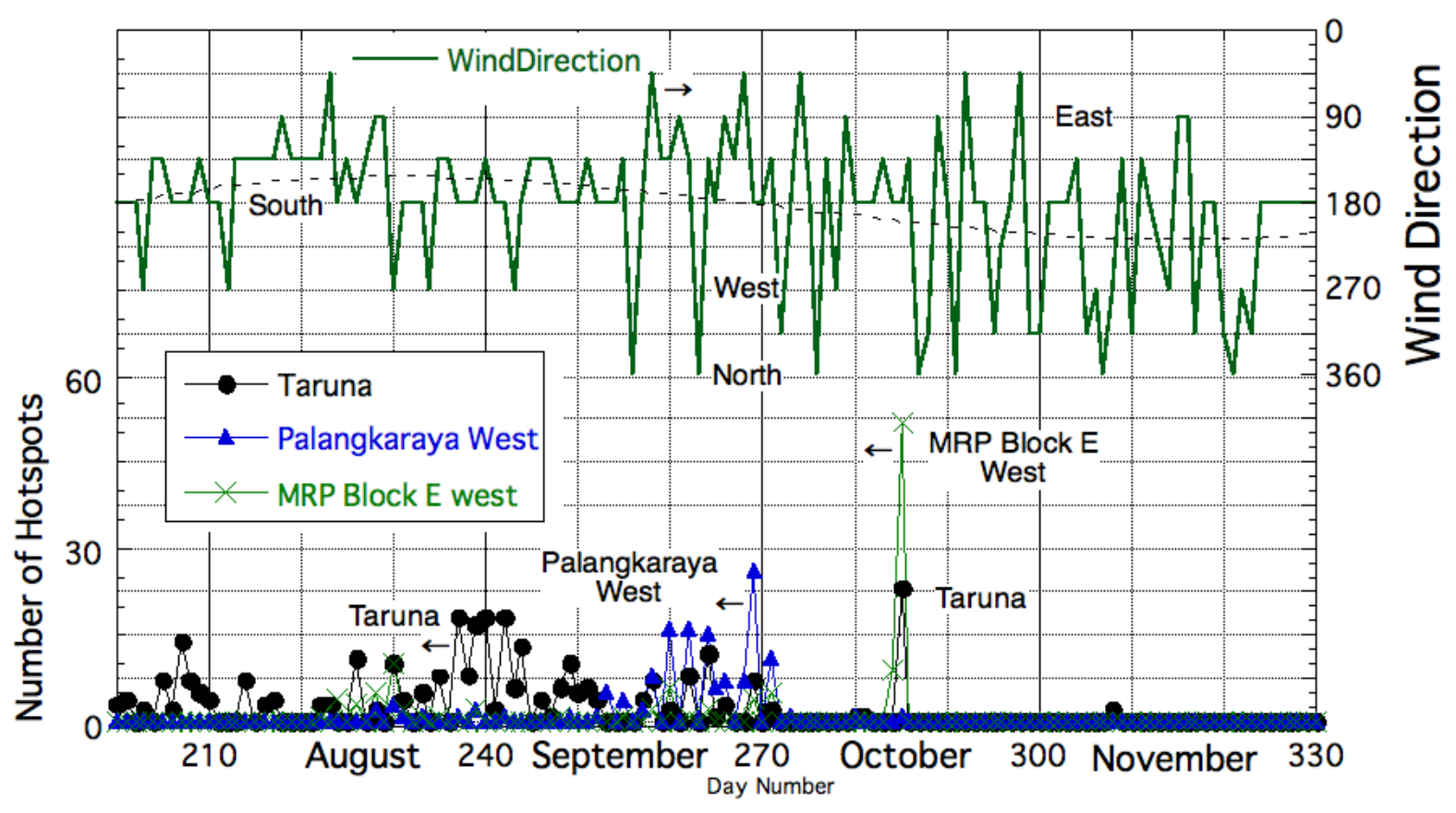

Fig. 12 Hotspots and wind direction. 
Table 1 Air Pollutant Concentrations

\begin{tabular}{|c|c|c|c|c|c|c|c|c|c|c|c|c|c|c|c|c|c|c|}
\hline \multirow{3}{*}{ Site } & \multirow{3}{*}{ Data set } & \multicolumn{6}{|c|}{ Gas } & \multicolumn{11}{|c|}{ Aerosol } \\
\hline & & $\mathrm{SO}_{2}$ & $\mathrm{HNO}_{3}$ & HONO & $\mathrm{HCl}$ & $\mathrm{NH}_{3}$ & $\mathrm{NO}_{2}$ & $\mathrm{SO}_{4}{ }^{2-}$ & $\mathrm{NO}_{3}^{-}$ & $\mathrm{CI}$ & $\mathrm{NH}_{4}^{+}$ & $\mathrm{Na}^{+}$ & $\mathrm{K}^{+}$ & $\mathrm{Ca}^{2+}$ & $\mathrm{Mg}^{2+}$ & $\mathrm{F}^{-}$ & $\mathrm{EC}$ & OC \\
\hline & & \multicolumn{6}{|c|}{$\mathrm{ppb}$} & \multicolumn{11}{|c|}{$\mu \mathrm{g} \mathrm{m}^{-3}$} \\
\hline \multirow[t]{3}{*}{ Taruna jaya } & 19-24 Sep. 2010 & 0.13 & 0.11 & 0.31 & 0.07 & 7.87 & 1.55 & 1.37 & 0.06 & 0.03 & 0.23 & 0.04 & 0.13 & 0.00 & 0.00 & 0.04 & 1.76 & 6.83 \\
\hline & 15-22 Aug. 2011 & 0.38 & 0.40 & 0.52 & 0.72 & 15.47 & 4.24 & 8.28 & 0.30 & 0.18 & 1.30 & 0.26 & 0.96 & 0.01 & 0.02 & 0.11 & 4.96 & 28.17 \\
\hline & 29 Aug.-5 Sep. 2012 & 0.31 & 0.27 & 0.26 & 0.41 & 7.66 & 1.65 & 7.38 & 0.13 & 0.06 & 1.36 & 0.12 & 0.49 & 0.02 & 0.01 & 0.06 & 2.99 & 16.54 \\
\hline \multirow[t]{3}{*}{ UNPAR } & 17-22 Aug. 2011 & 0.95 & 0.33 & 0.68 & 1.47 & 29.80 & 6.57 & 10.94 & 0.95 & 1.09 & 2.54 & 0.30 & 1.22 & 0.02 & 0.02 & 0.22 & 5.96 & 87.92 \\
\hline & 29 Aug.-5 Sep. 2012 & 0.33 & 0.38 & 0.30 & 0.79 & 7.90 & 2.64 & 7.41 & 0.21 & 0.12 & 1.28 & 0.17 & 0.59 & 0.02 & 0.02 & 0.06 & 2.79 & 22.49 \\
\hline & \multicolumn{3}{|c|}{ UNPAR: University of Palangka Raya } & & & & & & & & & & & & & & & \\
\hline
\end{tabular}

Table 2 Air Pollutant Concentration Ratios

\begin{tabular}{|c|c|c|c|c|c|c|c|c|c|c|c|c|c|c|c|c|c|}
\hline Data set & $\mathrm{SO}_{2}$ & $\mathrm{HNO}_{3}$ & HONO & $\mathrm{HCl}$ & $\mathrm{NH}_{3}$ & $\mathrm{NO}_{2}$ & $\mathrm{SO}_{4}{ }^{2-}$ & $\mathrm{NO}_{3}^{-}$ & $\mathrm{CI}$ & $\mathrm{NH}_{4}^{+}$ & $\mathrm{Na}^{+}$ & $\mathrm{K}^{+}$ & $\mathrm{Ca}^{2+}$ & $\mathrm{Mg}^{2+}$ & $\mathrm{F}^{-}$ & $\mathrm{EC}$ & $\mathrm{OC}$ \\
\hline 2011 Taruna jaya/2010 Taruna jaya & 3.0 & 3.6 & 1.7 & 9.8 & 2.0 & 2.7 & 6.0 & 5.3 & 5.4 & 5.7 & 6.6 & 7.6 & 2.4 & 6.3 & 2.7 & 2.8 & 4.1 \\
\hline 2012 Taruna jaya/2010 Taruna jaya & 2.4 & 2.4 & 0.9 & 5.6 & 1.0 & 1.1 & 5.4 & 2.2 & 1.7 & 6.0 & 3.0 & 3.9 & 4.6 & 4.7 & 1.3 & 1.7 & 2.4 \\
\hline 2011 UNPAR/2011 Taruna jaya & 2.5 & 0.8 & 1.3 & 2.0 & 1.9 & 1.5 & 1.3 & 3.2 & 6.2 & 1.9 & 1.2 & 1.3 & 1.5 & 1.1 & 1.9 & 1.2 & 3.1 \\
\hline 2012 UNPAR/2012 Tarna jaya & 1.1 & 1.4 & 1.1 & 2.0 & 1.0 & 1.6 & 1.0 & 1.7 & 2.1 & 0.9 & 1.4 & 1.2 & 0.8 & 1.2 & 1.1 & 0.9 & 1.4 \\
\hline 2011 UNPAR/2012 UNPAR & 2.9 & 0.9 & 2.3 & 1.8 & 3.8 & 2.5 & 1.5 & 4.5 & 9.4 & 2.0 & 1.7 & 2.1 & 1.0 & 1.3 & 3.5 & 2.1 & 3.9 \\
\hline
\end{tabular}

Table 3 Air pollutant concentrations at reference sites in East Asia.

\begin{tabular}{|c|c|c|c|c|c|c|c|c|c|c|c|c|c|c|c|}
\hline \multirow{3}{*}{ Country } & \multirow{3}{*}{ Site } & \multicolumn{6}{|c|}{ Gas } & \multicolumn{8}{|c|}{ Aerosol } \\
\hline & & $\mathrm{SO}_{2}$ & $\mathrm{HNO}_{3}$ & HONO & $\mathrm{HCl}$ & $\mathrm{NH}_{3}$ & $\mathrm{NO}_{2}$ & $\mathrm{SO}_{4}{ }^{2-}$ & $\mathrm{NO}_{3}^{-}$ & $\mathrm{Cl}$ & $\mathrm{NH}_{4}^{+}$ & $\mathrm{Na}^{+}$ & $\mathrm{K}^{+}$ & $\mathrm{Ca}^{2+}$ & $\mathrm{Mg}^{2+}$ \\
\hline & & \multicolumn{6}{|c|}{$\mathrm{ppb}$} & \multicolumn{8}{|c|}{$\mu \mathrm{g} \mathrm{m}^{-3}$} \\
\hline Cambodia & Phnom Penh* & 1.30 & 0.20 & - & 0.40 & 10.50 & - & 2.70 & 1.16 & 0.22 & 0.45 & 0.57 & 0.54 & 0.75 & 0.12 \\
\hline China & Hongwen* & 5.80 & 2.10 & - & 13.30 & 9.50 & 20.20 & 17.60 & 11.66 & 1.51 & 5.85 & 1.62 & 0.72 & 1.59 & 0.31 \\
\hline Indonesia & Serpong* & 1.40 & 0.80 & - & 0.70 & 11.00 & - & 0.65 & 0.57 & 0.10 & 0.32 & 0.16 & 0.37 & 0.18 & 0.05 \\
\hline \multirow[t]{2}{*}{ Japan } & Tokyo* & 1.60 & 0.60 & - & 0.80 & 4.40 & - & 4.06 & 3.76 & 0.70 & 1.57 & 0.89 & 0.17 & 0.49 & 0.13 \\
\hline & Sapporo\# & 2.42 & 0.32 & 1.07 & 0.82 & 1.82 & 16.36 & 3.08 & 1.34 & 0.86 & 1.16 & 0.69 & 0.13 & 0.17 & 0.08 \\
\hline Malaysia & Petaling Jaya* & 2.00 & 0.70 & - & 0.80 & 6.70 & - & 4.22 & 1.14 & 0.11 & 1.12 & 0.32 & 0.34 & 0.37 & 0.04 \\
\hline Mongolia & Ulaanbaatar* & 6.10 & 0.20 & - & 1.10 & 8.70 & - & 4.11 & 1.81 & 1.18 & 1.80 & 0.20 & 0.29 & 3.35 & 0.38 \\
\hline Russia & Irkutsk* & 5.60 & 0.10 & - & 1.40 & 1.70 & - & 2.28 & 0.88 & 0.43 & 0.62 & 0.28 & 0.25 & 0.35 & 0.09 \\
\hline Thailand & Bangkok* & 1.60 & 0.50 & - & 0.70 & 8.80 & 24.50 & 3.31 & 2.00 & 0.32 & 0.60 & 0.54 & 0.41 & 1.03 & 0.09 \\
\hline Vietnam & Hanoi* & 1.90 & 0.90 & - & 2.00 & 6.40 & - & 14.40 & 6.82 & 1.33 & 4.50 & 0.67 & 0.85 & 8.67 & 0.35 \\
\hline & \multicolumn{4}{|c|}{ *: Annual mean of 2011 by EANET Data report } & \multicolumn{8}{|c|}{ \#: Annual mean of FY 2011 by JELA Data report } & & & \\
\hline
\end{tabular}

